Our Traditional Prosody and an Alternative

Author(s): M. A. Bayfield

Source: The Modern Language Review, Vol. 13, No. 2 (Apr., 1918), pp. 157-182

Published by: Modern Humanities Research Association

Stable URL: http://www.jstor.org/stable/3714261

Accessed: 25-12-2015 07:08 UTC

Your use of the JSTOR archive indicates your acceptance of the Terms \& Conditions of Use, available at http://www.jstor.org/page/ info/about/policies/terms.jsp

JSTOR is a not-for-profit service that helps scholars, researchers, and students discover, use, and build upon a wide range of content in a trusted digital archive. We use information technology and tools to increase productivity and facilitate new forms of scholarship. For more information about JSTOR, please contact support@jstor.org. 


\section{OUR TRADITIONAL PROSODY AND AN ALTERNATIVE.}

Touch. This is the very false gallop of verses:

why do you infect yourself with them?

Ros. Peace, you dull fool, I found them on a tree.

Touch. Truly, the tree yields bad fruit.

As You Like It.

\section{BLANK Verse.}

THE object of this paper is to show that English blank verse is written to a metrical scheme which proceeds on $a$ trochaic base $(-\cup)$, and that our accepted prosody, which assumes an iambic base $(\checkmark-)$, is not only grounded on radical misconceptions of the whole matter, but also continually breaks down when tested by the work of the poets. From occasional references in works on English prosody I gather that the trochaic base is not now proposed for the first time, but I have not been able to discover any book or magazine article in which it is advocated ${ }^{1}$.

Let me say at the outset that I recognise stress rather than quantity as the dominating factor in our prosody, since verse, with rare exceptions, abserves the rules of ordinary pronunciation. On the other hand, most of our stressed syllables are actually long, and a quantitative notation has hitherto been usually and not unnaturally employed in works on English prosody. For these reasons, and because it will be more convenient for setting forth both the accepted system and that now offered, I shall use this notation, although it is so largely conventional. Thus a short $i$, as in pity, will, if stressed, be treated as a long syllable. Long syllables, when they take no stress and count as shorts, as capp'd in cloud-capp'd towers, will be described as 'irrational longs,' or briefly as 'irrationals,' and indicated by the symbol $>$. Other symbols used are $\checkmark$ to denote a short syllable (A); - to denote a long (theoretically twice the length of $u$, as $J=\sqrt{J}$ ); $\llcorner$ to denote a long protracted to the length of three shorts, and $\wedge$ to mark a pause of the length of $\cup$. The

1 Since writing this paper, I have been informed that some German prosodists now scan German verse on a trochaic base. 
recognised term 'foot' will be used to describe a metrical unit. The numbering of lines quoted from Shakespeare is that of the Globe edition.

According to the persistent tradition, originally founded, as I believe, on a confusion of metre with rhythm, the norm of the heroic line consists of a succession of five feet, each of which is an iambus $(\checkmark\lrcorner)$; a long syllable may, however, replace any short, making the foot into what is termed, but improperly, a spondee, - - . Thus the normal scheme given is

$$
=-10-10<10-10-11 .
$$

This scheme probably obtained acceptance because the Greek iambic line used to be so. scanned, but for more than forty years now that scheme has been abandoned. It was found that Greek prosody as a whole must remain as incoherent and unintelligible as it had always been from postclassical times, unless the foot in all measures began with the stressed or chiefly stressed syllable. Accordingly for metrical purposes Greek scholars now divide the line thus,

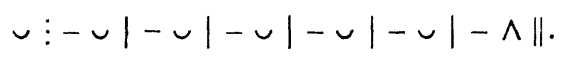

The six feet are counted from the first long, and the last foot is not completed. The initial syllable, of which more will be said below, is only introductory to the measure. As a metrical foot, therefore, $\checkmark-$ no longer receives any support from Greek prosody, and its claims to be so employed must be considered solely on their own merits.

It is true that much of our verse can be made to conform to the traditional scheme-all lines, for instance, like

To sleep ; perchance to dream: ay there's the rub;

but from Chaucer onwards we find a large number of lines, considerably more than half the heroic verse written, that are incapable of being fitted to a measure composed of such feet. The following are examples, scanned as by these or those of the prosodists:

(a) Háve I | nót in | a pítch'd | báttle | heárd. T. S. 1. 2. 206.

(b) $\wedge$ Knéel | thou dówn | Phílip, / but ríse / more greát. K.J. 1. 1. 161.

(c) What a háste / loóks through | his éyes!|'Só should | he loók. Mac. 1.2.46.

(d) Ánd his | gash'd stábs | loók'd like | a breách | in ná||ture. Mac. 2. 3.112.

(e) That mý | keen knífe | seé not | the woúnd | it mákes. Mac. 1. 5. 53.

$(f)$ The cú|riósi|ty of ná|tions to | depríve \| me. Lear, 1. 2. 4.

(g) ^ Whát | may yoú | be? Áre | you of goód | or é||vil? 0.5. 1. 65.

(h) To the lást | árti|cle : my lórd / shall név|er rést. 0. 3. 3. 22.

(j) $\wedge$ Sét $\mid$ at líber $\mid$ ty : the fát $\mid$ ríbs of $\mid$ peáce. $K . J .3 .3 .9$.

(k) Lét him / go, Gér|trude; dó| not féar | our pér|ison. Ham. 4. 5. 122.

(l) Hére is | himsélf, | márr'd, as | you seé, | with traí||tors. J. C. 3. 2. 201.

(m) $\wedge$ Thén | the whí|ning schoól-|boy wíth | his sátch||el. A.Y.L. 2. 7. 144.

(n) O mónst|rous áct!| -Vílan|y! vill|any! vill||any! O. 5. 2. 190. 
(o) Márry | and amén, | how sound is she asleep! R.J. 4. 5. 8.

(p) $\wedge$ Sáve $\mid$ what béats $\mid$ there. Fíli|al ingrát|itúde. Lear, 3. 4. 14.

iq) The bód $\mid$ y's déli|cate : the témp|est in $\mid$ my mind. Lear, 3. 4. 12.

$(r)$ Twéaks me | by the nóse? | gives me | the lie | i' the thróat? Ham. 2. 2.601.

(s) "Fíer|y"! whát, | "quáli|ty"! Why, Gloú|cester, Gloú||cester. Lear, 2. 4. 97.

(t) Stéw'd in|corrúp|tion, hóney|ing and má|king lóve. Ham. 3. 4. 93.

One would have thought that anyone seeking to. accommodate English verse to an iambic base would have abandoned the enterprise when faced by such an array of refractory lines as these typify; but as the scansions show, rather than be beaten, some ingenious person invented an astounding device called 'reversed stress' or 'inversion,' by which some of the feet are given a stress $-\checkmark$ exactly the opposite of $\checkmark-\dot{ }$. The enormity perpetrated in this stroke of genius is so glaring, the trick so absurd and childish, that one wonders how it ever came to be countenanced by anyone but its desperate author. It violates two fundamental principles of poetic measure, which are in fact adhered to in the iambic norm as given above, and are therefore tacitly admitted by its adoption. These are $(a)$ that a measure must be compounded of units of equivalent value, and $(b)$ that its rhythm or movement must be continuous. At the same time this device obliterates the essential distinction between the rhythm of verse and that of prose. In the former, if we are to have ' measure,' the stresses must occur at regular intervals, in the latter they must not do so to any considerable extent; and if a prosodist offers us as measure such a sequence of feet as $v-|-v| v-|-v| v-$, he is putting us off with the rhythm of prose. It is as little permissible, save as an exception, to invert the stress in verse as it is in music. Such exceptions do indeed occur occasionally both in music and in verse, but when the inversions are so frequent as to be normal, the verse equally with the music becomes a 'rag-time.'

Before discussing this scansion further it will be convenient to notice the view of some scholars of learning and distinction who, since they refuse to admit any but disyllabic feet in Shakespeare's verse, save under absolute compulsion, may without offence be called disyllabists. They of course postulate inversion. Starting from the unproved assumption that his constant aim was to write lines without resolved feet, they tell us he pronounced as follows in the lines quoted above: 'cu| rios't $\mid y$ of na|tions-Villan|y, vill'|ny, vill' $\mid$ ny - th'nose...th'throatThe bod $\mid y$ 's del'|cate: th'tem|pest—qual'ty—hon'ying.' The following further specimens of the method are a few out of many hundreds mostly taken from Goswin Koenig's Der Vers in Shaksperes Dramen, the accepted authority on the point at the present time: 'pill'ry, mag'cal, 
pen'ry, Hel'na, partic'lar, ridic'lous, des'late, perspic-yous, It'ly, wom'nish, Jess'ca, pit'ful, sorr'wful, Im'gen, prod'gal, conf'dent, app'tite, Jup'ter, vi'lent, ignom'ny or ignomy, duch'ss, do'ng, the'tre, dite (diet), quitely (quietly), de'ty, Prime (Priam), Plantajnet, th'breach, whi'r (whither), nour'sher, how came w'ashore?' It will be noticed that some of the combinations of consonants are not to be achieved without a splutter, and sometimes the aspirated $h$ must be dropped, as in

\section{Fier|y ? th'f'|ry duke?| Tell th'hot (th'ot)|duke that-.}

The pronunciation of proper names varied in successive lines, as in ' 'Tis death for any one in Mantua To come to Pad'a' (Pajja?), and 'If Alcibi'des kill my countrymen, Let Alcibiades know this of Timon.' And being no humourist or even a punster, Shakespeare could make that 'most del'cate fiend' the Queen in Cymbeline say (for evil-eyed) eel-eyed unto you, and make another say of her that she repented

The eels she hatch'd were not effected. 5. 5. 60.

It need hardly be said that practically every word in Koenig's enormous list occurs also in positions where the full pronunciation is required even with the ten-syllable scansion. We are to believe, therefore, that two kinds of English were habitually spoken by the same characters and in the same scene on Shakespeare's stage, the one a poet's carefully syllabised English, and the other that which we associate rather with the 'Waterloo House young man.' As the Saturday Review once said of an author's style, 'if anyone likes this sort of thing, this is the sort of thing he would like'; but one must ask for better reasons than have been offered before believing that either Shakespeare or his public would have approved of it.

It is contended that the First Folio supports the disyllabic theory. That it does so to a considerable extent an opponent may readily grant, though it must be in the spirit of

Yes, forsooth, I wish you joy o' the worm ;

for in fact the Folio gives disyllabism its death-blow. To take but one play, $F_{1}$ of Richard $I I I$, as compared with $Q_{1}$, embodies some additions and divergences evidently made by Shakespeare himself, but it exhibits other variations which are no less obviously due to another hand. Among these changes I count 102 made solely with an eye to the metre, of which I take 8 to be assignable to the poet, while the origin of some seems uncertain; but it is of 63 made in order to abolish a trisyllabic foot or otherwise superfluous syllable that I now wish to 
speak $^{1}$. It is incredible that the resolutions should not be genuine in the Quartos, and equally incredible that Shakespeare should thus have put his own clock back, for back it is ; that question, however, is beside my present point, which is this. It is quite clear that the reviser of the text from which the Folio was printed, whether Shakespeare or another, found many trisyllabic feet and superfluous syllables which he set himself to eliminate; but if the recognised stage pronunciation in the following examples, for instance, was eels, perpechal, treach'rous, Bucknam, why did he make the change? There was nothing to alter.

Q. Of these supposed / evils, to / give me leave. 1. 2. 76.

F. Of these supposed crimes, to give me leave.

Q. 'To his : new | kingdon | of per|petual | rest. 2. 2. 46.

F. To his new kingdom of ne'er-changing night.

Q. Thy : age con|firm'd-proud, | subtle, | bloudy, | treacherous||. 4. 4. 171.

F. Thy age confirm'd-proud, subtle, sly, and bloody.

Q. My :lord, the | army | of the | duke of | Buckingham||. 4. 4. 508.

F. My lord, the army of great Buckingham.

(Sly after subtle, and ne'er-changing night in this context, are delightfully grotesque, while great is not an epithet of Buckingham which the messenger would have dared to use to Richard on that occasion.) Similar evidence is furnished by all the other plays of which we have Quartos, excepting Per., M.W.W., M.Ado., L.L.L., which do not furnish any material. The present scrutiny alone, then, to say nothing of other evidence which will emerge later, conclusively proves that although the author or authors of the readings under discussion agree with the disyllabists in believing the heroic line to be better without resolutions, and may represent what was probably the prevailing view in Shakespeare's days, that view was certainly not his. It may be added that, as is well known, no reliance can be placed on the use of the apostrophe (in $t h$, to't, to's, for's, know'st, think'st etc.) in the early texts and especially $\mathrm{F}_{1}$, since it is quite arbitrary and casual, and sometimes even produces an unmetrical line.

Let us return to the prosodists who willingly admit resolution of the foot in their 'iambo-trochaico-anapaestic' scheme, and give the scansion indicated on pp. $158 \mathrm{f}$. above? ${ }^{2}$ We see that the original scheme, being found inapplicable to thousands of lines, has been so modified by the introduction of new and contradictory feet that it is now unrecognisable. The most conspicuous and startling of these intruders is the trochee, since

1 I shall be happy to send the complete list to anyone who cares to see it.

2 The principal recent expositions of this scheme are Saintsbury's History of English Prosody (3 vols. 8vo), and Manual of English Prosody, and J. B. Mayor's Chapters on English Metre (8vo) and A Handbook of Modern English Metres

M. L. R. XIII. 
its rhythm is precisely the opposite of that selected as the base of the system. In some lines, as $(a)$, it nearly ousts the iambus altogether, and would hardly leave a trace of it in $(g)(k)$, and none in $(m)$, but for what looks like sheer perversity. All these four lines cry aloud that they are trochaic with or without resolutions, and the iambus seems to be admitted simply for the purpose of 'savee facee.' In Shakespeare alone the type certainly forms an embarrassing phalanx of what Bacon calls instantiae contradictoriae. Other indispensable features consist in the assumption of one or even two 'hypermetrical' syllables at the end of numberless lines, and of the omission of a syllable at the beginning of many others. For this last device, called 'initial truncation,' Dr Saintsbury proposes a curious and equally impossible alternative-'strong monosyllabic anacrusis' (see p. 164 and footnote there).

As representing what we understand by 'measure,' the iambotrochaico-anapaestic system is obviously a no-system, a mere patch-work the very title of which one would have expected to awaken misgivings. For the substitution of the trochee no justification or precedent, so far as I am aware, has ever been offered. As to the other feet employed, the

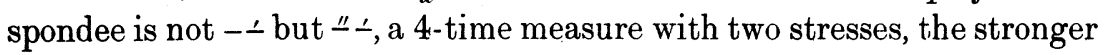
of which is on the first; and the anapaest is not $\checkmark\llcorner$ but " $\checkmark \leftarrow$, also a 4-time measure and stressed similarly to the spondee. The amphibrach $\checkmark \sim \checkmark$, again, is a 4-time measure; it denotes a prose rhythm only, and was not used by the ancients as a metrical foot. None of these, therefore, could alternate with 3 -time measures such as $\checkmark-$ and $-\checkmark$. Lastly, the tribrach is $\backsim \cup \cup$, not $\checkmark \dot{\cup} \cup$. And what has become of continuity of rhythm when stresses are assigned hap-hazard to the last or first or middle syllable of the feet of a measure?

The effect of 'inversion' upon hundreds of lines is to rob them of a foot. For instance, the prosodists may give us on paper,

$\wedge$ Knéel | thou dówn | Phílip, | but ríse | more greát ||, but when the line is uttered we hear,

Knéel thou dỏwn $\mid$ Phílip, but $\mid$ ríse more $\mid$ greát $\wedge \mid-\sim \|$ :

down has become a slightly stressed irrational long in a resolved foot, and we have a 4-foot line on a trochaic base. ' It is only by marking a pause after down that we can get five feet and show the line's true rhythm:

Knéel thou | dówn $\wedge \mid$ Phílip, but | ríse more | greát $\wedge \|$.

If this is not enough, there is yet another result, which should give this monstrosity its coup de grâce. The Greek poets, the delicacy of 
whose ear will hardly be questioned, used a measure called the dochmiac, which is composed of two unequal feet, a bacchius ( It began with an anacrustic syllable $\checkmark$, and might be either 'full' or 'checked': $\bullet \vdots--\checkmark \mid-\checkmark \|$ or $\checkmark \vdots--\checkmark \mid-\wedge \|$. The value of the measure lay in its irregularity; and as presenting the greatest conceivable contrast to the smoothness of all even measures, it was invented and employed solely to express the extreme of passionate emotionuncontrollable grief, agitation, fury, distress. Our own poets have, I believe, never used the measure even in experiments, but the prosodists give it to us in line after line. When they $\operatorname{scan}(K . J .1 .1 .193)$,

My pịck'd | mán of | coúntries: | My dĕar | sír,'

Thus, leán|ing on my elbow, I begin,

they make us utter, with delightful incongruity, two full dochmiacs in succession :

My̆ : .pīck'd mān of | coūntrres: || 'My̆ ! dēar sīr,' thŭs, | leānYng ||.

The following specimens are also from $K . J$ :- -and roúgh $\mid$ frówn of $\mid$ wár $\wedge$; that láw $\mid$ bâr no $\mid$ wróng $\wedge$; and loud churlish drums; the fat ribs of peace. The play is made to exhibit about a dozen perfect examples, while of course the dochmiac's characteristic irregularity vexes the ear with every inversion that brings two longs together.

It was said above that the Greek iambic line is now scanned in feet which have their stress on the first syllable; the same is true of all Greek measures, and this seems to be the natural mode of division. It was the method instinctively adopted when music was first written down in bars, although many musical themes begin with an unstressed note; and considering the close analogy between music and verse, to mark off the units of a verse measure otherwise seems as unnatural as it would be to divide the notes of a waltz into bars each of which begins with the third beat. Now, there frequently occurs in Greek poetry a 5-foot measure with a trochaic base which is demonstrably the measure to which our heroic line is written. Its norm.is

$$
\checkmark \vdots-v|-v|-v|-v|-v \| \text {. }
$$

The introductory syllable, marked off by the sign :, although an invariable adjunct of some Greek measures, is in many (including this pentapody) inserted or omitted at pleasure in successive lines; just as in music a recurrent theme sometimes appears with an introductory note and sometimes without. It is called, from the analogy of the musical conductor's baton, the anacrusis or upbeat. Being an upbeat, it does not take stress (or not more than the, secondary stress of measures that 
have two), and must not exceed in length the unstressed part of the measure to which it is attached ${ }^{1}$. Thus in a measure of triple time, like this one, it must not be longer than $\checkmark$. It may however, be an irrational long, or it may consist of two half-shorts $(\sim=v)$. The opening lines of Horatius afford an excellent illustration:

Lảrs : Porsen|a of | Clusium, ||

By the nine / gods he | swore $\wedge||$

That the $\vdots$ great | house of | Tarquin ||

Shoủld $\vdots$ suffer $\mid$ wrong no $\mid$ more $\wedge \|$.

The 1st, 2nd, and 4th lines show the irrational, and the 3rd the double upbeat.

The following variations are normal both in the Greek line and our own: (1) the long of the trochee is protracted to the time of 3 shorts, forming a monosyllabic foot $L$, as in v. 3 of Horatius; (2) the trochee is resolved into $(a)$ the triplet dactyl $\sim \cup$, the syllables of which have the values $1 \frac{1}{2}, \frac{1}{2}, 1$; or $(b)$ the tribrach $\cup \cup v$; or $(c)$ the unnamed $-w$, a long and two half-shorts; or $(d)$ occasionally into a quadrisyllabic foot. (The triplet dactyl is to be distinguished from the true 4-time dactyl " $\cup$, which has two stresses.) The resolutions are exemplified by furious, pitiful, dead for a (ducat!), and marry, to con(fess).

The Greeks used indifferently and in succession $(a)$ the full measure. which is that of the Divina Commedia,

Nel : mezzo | del cam |min di | nostra | vita, ||

and of lines like

I : come to | bury | Caesar, | not to | praise him ||,

and $(b)$ the 'checked' line with the last foot incomplete, as

But : let them | measure | us by | what they | will, $\wedge \|$

We'll ${ }^{\circ}$ measure $\mid$ them a $\mid$ measure $\mid$ and be $\mid$ gone. $\wedge$ \|

Our own poets do the same, but for good reasons use chiefly the checked line, employing the other only as a variety.

The notion that the last syllable of the full measure is 'hypermetrical' and a 'licence' is, as we now see, in plain opposition to the fact, if any weight is to be attached to the various evidence that is forced upon us. The unmistakable view of our poets will emerge more plainly when we come to examine their verse in detail, and one wonders

1 Dr Saintsbury falls into disastrous error on this point, which is of fundamental importance. He strangely mistranslates anacrusis by 'push-off or take-off,' and so, to take a single illustration, describes the line Phil|lida floúts | mé (for so he scans and recites !) as having an 'anacrusis of one strong monosyllable' $(H . E$. $P$. vol. II, p. 336), thus giving to his anacrusis Phil-a stress equal to that of the ictus of the measure and in effect making it into a whole foot. His whole system is largely based on this astounding mistake. 
whether Dr Saintsbury felt no qualms as to his logic when he wrote on this point,

The first of these features probably, and the most insidious, but also the most revolutionary, is the redundant syllable. It is of an ancient house; we had ourselves fifteeners before we had fourteeners, and in all prosodies from the Greeks downwards there has been a tendency to regard the last place in a line as a place of licence and liberty. It is a sort of 'breath' only, something you do not count, but just smuggle in with its companion ${ }^{1}$.

If the Fifteeners (to transfer the name from the verse to its writers), following the habit of an ancient house, were engaged in importing this sort of breath openly, as they were, they can hardly have expected or wished to escape observation, and it seems unfair to call their practice smuggling. Such breaths are things that anyone might notice. Nor can they have been revolutionaries; the term belongs rather to the Fourteeners, who interfered with what had hitherto been regarded as legitimate trade. To speak in plain prose, it is obvious that what the latter did was to dock the line in vogue of a syllable which, so far from being hypermetrical, was clearly an integral part of its final trochee.

As Chaucer had done before him, Shakespeare at once developed in his handling of the measure every variation with which the Greek line had been embellished. For instance, we find in so early a play as Love's Labour's Lost,

How will he $\mid$ scorn $! \wedge \mid$ how will he $\mid$ spend his $\mid$ wit $! \wedge \|$

I be : seech you, a $\mid$ word : $\wedge \mid$ what is $\mid$ she in the $\mid$ white? $\wedge||$

His ear for music recognised, as Chaucer's had done, the rhythmical beauty of the resolved foot, and so far was he from seeking to avoid it, that he used it with ever-increasing frequency, often introducing a quadrisyllabic, and in four cases a quinquesyllabic; while he frequently gives us a trisyllable even in the final foot, as Macaulay does in the first line of Horatius. One feature he added which is not found in Greek poetry -a pause within the line of the time of a short syllable, as in the two lines just quoted. This is to be distinguished from the lengthening of - to $L$, and is similar to the normal omission of the measure's fina. syllable.

Before proceeding to show by examples and point by point the trochaic structure of our measure, and incidentally its remarkable identity with the Greek prototype, it may be well to forestall some possible objections and misapprehensions.

It may be laid down as indisputable that the rhythm of verse

1 H. E. P. vol. II, p. 50. The italics are mine. 
corresponds to that of music; conceivably at least, all verse could be set to music without change of its rhythms. But in music that is properly interpreted it continually happens that of half-a-dozen consecutive bars no two take up exactly the same amount of time, while the notational values of the individual notes will be habitually departed from at least to some small extent. So it is in the utterance of verse (and we must remember that all verse is meant to be spoken aloud), but with much greater latitude; one foot will take the normal length of time, one or two or more will be said more slowly, others faster. Again, we useour language compels us to use, a large number of 'irrationals,' and individual words with a significance that needs to be brought into relief occur far more often than is the case with individual notes of music. Owing to these two facts combined, the spoken - $\checkmark$ will often become a

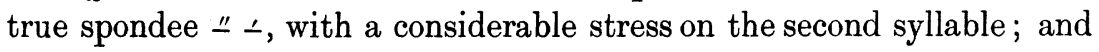
the resolved foot will undergo even greater modification, though it will never fail to be recognisable as being approximately of one of the four types mentioned above. Nevertheless the rhythm is always preserved, because we find no difficulty in distributing the normal stresses. There are of course limits to the use of heavy irrationals, but within those limits we may say that the measure was made for the poet, not the poet for the measure. Although therefore we may, in order to facilitate explanation, legitimately apply the musical or quantitative notation of - and $\checkmark$ to verse, we do not imply that the movement of verse is in all respects similar to that of music. The remark may seem needless, but it is important; for many people deny that English poetry can be usefully marked off in this manner simply from a failure to recognise the compatibility of two facts,- - that on the one hand the movement of verse is essentially orderly, is in fact a rhythm, and on the other, that the time-values of the quantitative notation are not slavishly and inartistically observed when the words are spoken aloud.

These remarks may be briefly illustrated. In saying the line,

To sleep; perchance to dream : ay there's the rub :

we retain almost exactly the true musical values of the syllables, but at the same time we depart from the more even flow of music by making long pauses at sleep and dream, and a short one after ay. But the spoken trochee often becomes a pyrrhic $(\bullet \checkmark)$ :

Elaine the fair, Elaine the | lova|ble,

Elaine the | lily | maid of Astolat,

High in her chamber | up a | tower to the east. 
This, however, and the fact that the foot sometimes becomes an apparent spondee, should not lead us to call the rhythm of English poetry 'duple' that is, to regard the normal unit as - - rather than $-v$, as Mr Omond is inclined to do; the prevailing character of our verse as a whole, and of these lines in a remarkable degree, forbids such a view. The phenomenon often occurs in music, as when we get two quavers replacing a triplet. Mr Omond's difficulty would probably disappear with recognition of the irrational long. This syllable is sometimes so heavy that, as was said above, the foot as spoken becomes a true spondee, as in Macbeth's Máking the | grëen óne | rëd. Similarly the last syllable of a triplet dactyl is not infrequently heavy, as in the third foot of the line,

Is a $\vdots \operatorname{sharp~|~wit~|~match'd~with~too~|~blunt~a~will.~L.~L.~L.'~2.1.49.~}$

Lastly, it is common for the first syllable of a foot to take no stress at all; to which music again affords a parallel.

What has been said here is of no little importance for yet another reason,- that without an appreciation of the musical rhythm of verse, effective utterance of it is unattainable; it will sound like prose. We may now proceed with our illustrations.

\section{The Trochaic Scheme Illustrated.}

We have seen that the trochaic system is at any rate sound in principle. It provides the first and strictly indispensable requisite for any prosodic scheme-continuity of rhythm. It places the stress where by Greek precedent and musical analogy it should be, on the first syllable of the foot; it explains why the initial syllable of the line is sometimes stressed and sometimes not; and it accounts for the presence of three or even more syllables in the foot, as a natural resolution of the trochee on principles familiar to us in music. It also explains how two stressed syllables can occur together through the protraction of the long in a monosyllabic foot, and it relieves us of the necessity of bringing against the poets the unfounded charge that they habitually violate their measure by 'smuggling in' a 'redundant' syllable or syllables at the end. We have now to submit the system to the crucial test of application: does it work? For this purpose let us examine the handling of the heroic line by four of its greatest masters, taking the features of the scheme one by one'.

1 In the following pages S. at the end of a line quoted indicates Shakespeare, M. Milton, T. Tennyson, and Sw. Swinburne. 
1. The Upbeat. The proportion of lines without upbeat appears to be nearly as follows : in Shakespeare, Milton, and Tennyson 1 in 5 ; in Swinburne's Atalanta 1 in 4. The omission, which seems to occur whenever it is convenient, may be made for the purpose of giving great or moderate emphasis to the first word, as in Brutus will start a spirit as soon as Caesar ; but often there is no emphasis at all, as when the Nurse asks Juliet, Have you got leave to go to shrift to-day? The effect of the mere omission (i.e. without resolution of the first foot) upon short measures is remarkable; as a rule it gives additional liveliness and energy, as in L'Allegro, where nearly half the lines have no upbeat. In Il Penseroso the proportion of omission to insertion is only 1 to 4 , as we should expect. On the other hand, if the subject and language are solemn, the omission adds to the solemnity, as in the hymn, Rock of Ages, cleft for me. A 5 -foot line usually loses in liveliness if it has no upbeat, unless the first foot is resolved; and even a short succession of pentapodies beginning $-\smile-\smile$ would be disagreeable if the rhythm had not an obvious purpose, as in Tennyson's Vision of Sin, II, and perhaps in the Wellington Ode, viII. Accordingly, when the upbeat is wanting in our measure, the first foot is almost always resolved, and lines like the following are comparatively rare :

(a) If I | talk to him, | with his innocent prate. S.

(b) Tantae/ne ani mis cae/lestibus | irae? S. 2 Hen. VI, 2. 1. 24.

(c) Uni|versal reiproach, far worse to bear. M.

(d) Now to / glorious / burial slowly borne. T.

(e) Tracks, and / gains on him, | scenting sins far off. Sw.

(f) Well, $\wedge \mid$ Suffolk, thou | shalt not see me blush. S.

(g) Senseless | linen! | happier there|in than I. S.

$(h)$ Tell the / clock there. ! Give me a / calendar. S.

(j) One word | more, good | lady. | What shall I | do? S.

(k) Yes, for $\mid$ sooth, I | wish you $\mid$ joy o' the $\mid$ worm. S.

(l) Quick, dis $\mid$ patch, and $\mid$ send the $\mid$ head to $\mid$ Angelo $\|$. S.

It will be observed that in the first six examples the line is at once relieved by a resolved foot. There are over 180 similar examples in Shakespeare, and 10 in Milton's Sumson. Sometimes two trochees precede the resolution, as in $(g)$ and $(h)$, and of this I count in Shakespeare 82 instances. More rarely he postpones the resolution to the 4th foot, as in $(j)$ and $(k)$, giving of this rhythm perhaps not more than 22 examples. In $(l)$ the final foot alone is resolved. In Swinburne 5 -foot lines beginning with a trochee are extremely rare.

Among the lines without upbeat there are two types which have a special interest from the fact that they happen to be identical with two Greek measures, the Phalaeceus hendecasyllabus and the Sapphic. The 
former, commonly called the hendecasyllabic, is a pentapody with one resolution only, in the 2 nd foot, and with the last foot completed. Shakespeare gives 30 examples, as

Brother, | give me thy | hand; and, gentle Warwick.

Villains, $\mid$ answer you $\mid$ so the lord protector?

In Milton I have noted two, both in choruses of Samson:

Uni|versally | crowned with highest praises. (175)

$\mathrm{O}$, how comely it is and how reviving. (1268)

Of the Sapphic, $-\cup|-v| \sim v|-v|-v^{\prime} \mid$, Shakespeare gives at least 25 instances, but $\mathrm{I}$ have not noticed it in Milton ${ }^{1}$ :

What may you be? | Are you of igood or evil? 0. 5. 1. 65.

Some time | I shall | sléep out, the | rest I'll| whistle. Lear, 2. 2. 163.

The occurrence of lines without upbeat, constituting as they do quite a fifth of all the heroic lines written, should of itself be sufficient to establish the trochaic base; but if further proof is needed, we find it in yet another variety of them which seems to settle the matter decisively. I mean such pure trochaic lines as

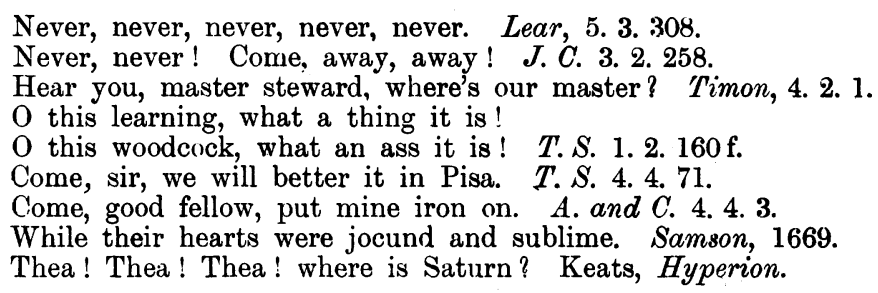

Of such lines I count in Marlowe's seven plays 66, and in all Shakespeare's 172 , but I may have missed one or two. The much greater proportion in Marlowe's work. or what passes for his, is instructive, as is also the distribution of the type among the genuine and disputed plays of Shakespeare. Such lines are characteristic of a versification not yet perfected; and although, with their blunt beginning and the absence of resolutions, they are effective in their proper place and when used sparingly, they tend to disappear as the playwright's craftsmanship improves ${ }^{2}$. My count gives for Shakespeare: T. S., J. C. 14; Per.

1 The Alcaic, $-\vdots--|-\sim| \sim-|--|-\wedge||$, is fairly frequent both in Shakespeare and Milton; there are eleven instances in Temp. i. 2, and five in Samson.

2 In The First Part of the Contention betwixt the Two Famous Houses etc., which was first published in 1594 and is the original of 2 Henry VI, I find in the first 1000 lines or so 15 such verses, and 12 beginning with two or three trochees. In its sequel The True 
13; 1 Hen. VI, 9; T. G., R. II, Macb., 8 each; Lear, Timon, Ham., 7 ; M. M., 2 Hen. VI, Hen. VIII, 6 each; Temp., 1 Hen. IV, 3 Hen. VI, Titus, Cymb., 5 each; Cor., 4. The other plays show 3, 2, 1 or none; I have noticed none in $M . W . W . M . N . D$., and Hen. V. Similar short lines also occur; there are for instance 5 in Lear. The total of pentapodies beginning with a trochee in Shakespeare's plays is over 450 . In Chaucer's Knightes Tale there are as many as 25, an average of one line in 90 .

If the mere existence of these lines does not convince us that their authors, known or unknown, must have scanned all their blank verse on a trochaic base, we must suppose that they adopted it occasionally in pure caprice. The prosodists, however, will not admit the base even for these lines; they tell us that the first syllable of the initial iambus is omitted! But we must reply that this, like the device of reversed stress, is only another bit of legerdemain. Such an 'omission' is incredible and unheard-of. There is another point too, which seems to have been overlooked, although it is of cardinal importance. It is all very well to print ' $\wedge$ Come, good fellow' but the words were primarily written to be spoken on the stage, and how can the actor indicate the omission before he has begun the line? A bibulous Antony might indeed start with a hiccup in order to suggest the iambic scansion,

uc ! Come, good fellow, put mine iron on,

but as a rule, even a gasp or a stammer would be hardly in place. Yet without some such elegant trick the actor must in each case utter a plain trochaic line. This, the effect on the ear, is the only test, and there is no escape from it.

2. The Jisyllabic Upbeat is frequent in all the poets; I have noted 42 instances in Hamlet, 41 in Othello, 26 in Macbeth, 96 in Lear. More often than not it is followed in Shakespeare by a monosyllabic foot, as in With a bare $\mid$ bodkin-Let him $\vdots$ go, $\wedge \mid$ Gertrude-With the : Moor,

Tragedie etc. (1595), the original of 3 Hen. VI, I count only 13 pure trochaic lines in the whole. It is interesting and instructive to compare

$\mathrm{f}$, now / lookes he like a king?

with

This is | he that tooke king Henries chaire. True Tragedie, 1.4.80 f.

Ay, marry, sir, now looks he like a king!

and

Ay, this is he that took King Henry's chair. 3 Hen. VI, 1. 4. 96.

f. if | thou saie / I to my request,

No, if thou saie no to my demand. True Tragedie, 3. $2.59 \mathrm{f}$.

with

Ay, if | thou wilt say | 'ay' to my request,

No, if | thou dost say |'no' to my demand. 3 Hen. VI, 3.2.79 f. 
$\wedge \mid$ say'st thou? In Swinburne's verse, owing to his love for resolutions, it is very common.

3. The Irrational Long sometimes takes a slight emphasis:

Of : whóse trủe-|fix'd and resting quality. S.

Bálm of hưrt $\mid$ minds, great nature's second course. S.

4. The Full Measure.-Completion of the last foot is normal, and resolution of it occurs in Shakespeare with some frequency. I have noted about 150 instances, not counting the large number composed of proper names, of which there are 54 in Antony and Cleopatra alone. Of the 150 Lear gives 21, Henry VIII 20, Tempest and A. and C. 17 each, Cymbeline 15; the other plays fewer. Examples are:

With $\vdots$ many $\mid$ heads $\mid$ butts me a|way. $\wedge \mid$ Nay, mother. Cor. 4. 1. 2.

0 : monstrous | act! $\wedge \mid-$ Villany! | villany! | villany! O. 5. 2. 190.

Eros :-I | come, my | queen.- $\wedge$ | Eros !- | Stay for me. A. and C. 4. 14. 50.

But his ! neat. | cookery! he | cut our | roots in | characters. Cymb. 4. 2. 49.

Beaumont and Fletcher, in imitation, exhibit the feature ad nauseam.

5. Resolution.-The resolved foot, which may take any of the forms already mentioned, has been a feature of our heroic line from its infancy. In Act $\mathrm{i}$ of Sackville and Norton's Gorboduc, the first dramatic blank verse published (1565), there is an average of 3 resolutions in every 17 lines; for example,

The realme divided | into two | sondry partes.

Stoode in the | likeli|hode to pos j sesse the whoke.

In Act 4 there is a quadrisyllabic,

With Serpentes | girt, $\wedge \mid$ carrying the | whip of ire.

In Chaucer's Prologue there is an average of more than one resolution in every 5 lines. In the plays of Shakespeare's maturity the average is 1 in $1 \frac{1}{2}$ to 2 lines, and sometimes there are two or even three or four in one line. In Lear there are 147 resolutions in 257 lines. His resolution of the 5th foot has just been noticed in $\$ 4$, and it is quite common for the 4 th foot to be resolved:

Look where he / goes, even | now, $\wedge$ | out at the / portal.

Next, your | son gone, and | he most / violent | author.

Seize upon Fife; $\wedge \mid$ give to the | edge o' the | sword.

Was he not | born of | woman? The | spirits that | know.

Dearly, my delicate Ariel. Do not approach.

The traditional scansion freely obscures the presence of resolutions to the eye, though of course not to the ear. Thus, if we scan, What is | amiss? | - You are, | and do | not know || it, the line appears to have no resolved foot; yet in fact it contains two: What is a miss? $\wedge \mid-Y o u$ are, and $\mid$ do not $\mid$ know it. 
It is important to notice that when an irrational in a resolved foot is heavy, rhythmical utterance of the words is often assisted either by a pause in the sense, or by the pause one naturally makes after a word to give it emphasis, as in

Dost thou | hear?-Your | tale, sir, would | cure | deafness.

Thou call'dst me up at $\mid$ midnight to $\mid$ fetch $\mid$ dew.

In Milton, who as a rule, composes the foot of syllables very easy to say, resolution is almost equally common; in $P . L$. I the average is 1 in $2 \frac{1}{9}$ lines. There are two in the opening line,

Of : man's | first diso|bedience | and the fruit, and, as in Shakespeare, occasionally three in one line:

Fled : over | Adria | to the Hes $\mid$ perian j fields.

Tennyson has an unmistakable liking for the resolution and is at pains to introduce it for effect :

In cataract after cataract to the sea.

Prick'd with incredible pinnacles into heaven.

O Galahad, and O Galahad, follow me.

Swinburne's love for the resolved foot is a veritable passion. In one passage in Atalanta there are 119 in 167 lines, and in another as many as 90 in 104 lines. Nineteen of these lines have two resolutions each, and in the former passage there are three having three each, and in the latter one such line. The effect produced by this accumulation is further heightened by the presence of quadrisyllabics, as in

Seeing thine | head | glitter and thine / hand | burn its way, (Alex.)

and by frequent double upbeats. The line has in fact become almost lyric, and is so different in character from the Shakespearean line, to say nothing of Milton's, that it might seem to belong to another metre. For although the blank verse of both the older poets is continually beautified by rhythms essentially lyric ${ }^{1}$, Swinburne's line exhibits this variation of the norm to an extent beyond that which in their judgement marked the desirable limit. Nevertheless it is not weaker. On the contrary, there is a gain of strength in a new direction, and the total result of this animation of the measure, reinforced as it is by frequent alliteration, is remarkable. There are in the play plenty of stately lines without resolution, yet not enough to stamp their character predominantly upon the whole; and while these lend dignity and nobility to the dialogue, the new line, which is full of emotion, conveys by its

\footnotetext{
1 See pp. 175 ff. infra.
} 
frequency an overruling impression of impetuosity and passion. Its effect is something like that of the galliambic. Examples are

Sunlike with many a Nereid's hair, and moved.

Through a heavy and iron furrow of sundering spears.

For silver nor | bright | snow nor feather of foam

Was whiter and no gold heavier than thine hair.

Where, hid by heavier hyacinth, violet buds

Blossom and burn; and fire of yellower flowers.

They are strong, they are strong; I am broken, and these prevail.

6. The Quadrisyllabic Foot.-The frequency of this foot in Shakespeare is sufficient to show what was his feeling about resolved feet in general ; there are, for instance, 18 each in Hamlet and The Tempest, 24 in Lear, 26 in Othello, 55, besides 2 quinquesyllabics, in Cymbeline.

The curi|osity of $\mid$ nations to deprive me.

Mumbling of wicked $\mid$ charms, $\wedge \mid$ conjuring the $\mid$ moon.

'Fiery'? | what, $\wedge$ | 'quality'? Why, | Gloucester, Gloucester.

Fiery? the $\mid$ fiery | duke? $\wedge \mid$ Tell the hot duke that-

The body's delicate : the tempest in my mind.

To every several man $\wedge \mid$ seventy-five | drachmas.

Abbott would scan the last line,

To ev'|ry sev'|ral man | se'nt'-fíve | dráchmas $\|$. or

To ev'|ry sev'|ral man | sénty-| five drách || mas.

Thus we are asked to believe that the actor who took the rôle of the incomparable orator Antony was expected by Shakespeare to deliver this important and weighty line, every syllable of which should tell, with 'slurring' or 'quasi-suppression' (Abbott) or actual elision (Koenig and others) of three if not four of its vowels, obscuring especially the precise sum of money to be given, which is equivalent to about £3.

It should be noticed that in Shakespeare the foot is often broken by a necessary or natural pause before the third or fourth syllable. In effect (and purpose) we have two short measures in the line, and the last or two last syllables of the quadrisyllabic form an upbeat for the second, as in

But his : neat | cookery ! || he $\vdots$ cut our | roots in | characters. Cymb. 4. 2. 48.

In each of the four following lines, which would be spoiled by being delivered as Alexandrines, we have a quinquesyllabic foot, and there are probably more in the plays :

Might : easiliest / harbour in? Thou blessed thing! Cymb. 4. 2. 206.

Murderous to the | senses? That confirms it home. Cymb. 4. 2. 329.

So : tediously a|way. The | poor con/demn'd | English. H. V. Act 4, Prot. 22.

Action is | eloquence, and the | eyes of the | igno|rant. Cor. 3. 2. 76. 
The following line of Tennyson shows both a quadrisyllabic and a quinquesyllabic :

Muttering and | murmuring at his | ear, $\wedge$ |'Quick! | Quick!'

In Milton also the foot is frequent; there are 22 in P.L. II and 19 in Samson:

Wallowing un/wieldy, enormous in their gait.

Irre $\mid$ coverably $\mid$ dark, $\wedge \mid$ total eclipse.

In Tennyson and Swinburne the foot is quite common, and often a thing of beauty:

Ruining a|long the il limit|able in |ane. $\mathrm{T}$.

Galloping of $\mid$ horses over the grassy plain. T.

Glittering as / wine and moving as a wave. Sw.

7. The Monosyllabic Foot.-(a) A long syllable protracted to the time-value of a whole foot, usually for emphasis, but not always; or $(b)$ the apparent deficiency of a short syllable accounted for by a pause of the voice. Both these features are common in the four poets under consideration, as also in Shelley, Keats, and Browning. I count an average of 1 in 7 lines in The Tempest, 1 in 9 in Hamlet, 1 in $7 \frac{1}{2}$ in Macbeth, and over 300 in Lear; in Milton P.L. I and II and Samson 1 in 14; in Comus 1 in 8; in Keats' Hyperion over 1 in 10; in Tennyson's Idylls 1 in 15 (but in particular idylls it is much more frequent); in Swinburne's Atalanta 1 in 5. The foot is usually followed by a resolution in order to ease the rhythm, but in Shakespeare a monosyllabic 4th foot is quite common.

The very | stones / prate of my whereabouts. S.

Than the $\vdots$ soft $\mid$ myrtle : but $\mid$ man, $\wedge \mid$ proud $\mid$ man. $\quad$ S.

Igno|miny in | ransom and | free / pardon

Are of $\mid$ two | houses: lawful mercy. S.

Nor Cymbe|line $\wedge$ | dream that they / are alive. $S$.

But not ap $\mid$ proach'd. $\wedge \mid$ All is $\mid$ well $\mid$ yet. S.

A $\vdots$ mind / not to be / changed by time or place. M.

Waiting re/venge. $\wedge$ Cruel his eye, but cast. $M$.

Whereby the | blood | beats, and the blossom blows,

And the : sea $/$ rolls, and all the world is warm'd. T.

And the

And thy mouth $\mid$ shuddering | like a $/$ shot $\mid$ bird. Sw.

In a line like the last we seem to have reached the utmost of the measure's possibilities; but the iambic system breaks down on it.

The monosyllabic foot, which is common in all Browning's verse, occurs with remarkable frequency in The Ring and the Book, and not having been recognised ${ }^{1}$, has given rise to the notion that the work is

1 See, however, a valuable article by the late Dr Verrall in the National Home-reading Union Magazine, Jan. and Feb., 1908. 
full of careless and unmetrical lines. Thus Dr Mayor is horrified by the 'inexcusable harshness or slovenliness' which he discovers (Handbook, p. 120). It would be truer to say that, being unsurpassed in his mastery of measures, the poet has here concealed his art with too much success. I give three examples out of eleven taken from the first 100 lines of Pompilia:

I am : just $\mid$ seventeen years and five months old, And, if I lived one day $\mid$ more, $\wedge \mid$ three full weeks. He will : seem | hardly more than a | great $\mid$ boy.

It is, indeed, no small part of the indictment to be made against our prosody, that it compels its champions to boggle over line after line of English poetry, and causes them to condemn or misrepresent many that are both rhythmically and metrically faultless. One of several extraordinary instances will be found in Dr Saintsbury's $H$. E.P. vol. II, pp. $231 \mathrm{ff}$. Dr Mayor's two books are similarly sown broadcast with painful failures.

It was said above (p. 172) that Shakespeare's blank verse habitually exhibits rhythms that are essentially lyric. In order to justify the statement, I must ask the reader to make a very brief excursion into Greek prosody.

Besides the plain lyric measures of two or more unresolved feet, the Greeks used the following among many others.

Dipody: $\quad(\alpha) \sim v \mid-\checkmark \|$, always without upbeat.

Tripodies: $\quad(\beta) \sim v|-v|-\cup \|($ lst foot resolved).

$(\gamma)-\checkmark|\sim u|-v \|($ 2nd foot resolved).

Tetrapodies: $(\delta) \sim \checkmark|-\checkmark|-\checkmark \mid-\checkmark \|($ 1st foot resolved).

$(\epsilon)-v|\sim \sim|-v \mid-v \|\left(\right.$ (2nd foot resolved) ${ }^{1}$

All these were used full or 'checked;' and singly or in combination. The tripodies and tetrapodies sometimes took upbeat, and were occasionally varied by an additional resolution and the introduction of monosyllabic feet.

It is not a little remarkable that Shakespeare's blank verse, especially in the plays which present it in its fullest perfection, frequently falls into one or other of these measures. I do not mean to imply that he borrowed them from a Greek or Latin source, which would be a possible but needless supposition; I would mereiy point out that his ear undoubtedly recognised and distinguished them, and that he must have employed them with intention. His types differ from the Greek only in

${ }^{1}$ (a) Versus Adonius, but not so called when 'checked'; $(\beta)$ 1st Pherecratean; $(\gamma)$ 2nd Pherecratean; (8) 1st Glyconic; (є) 2nd Glyconio. 
that he sometimes has a quadrisyllabic, and sometimes gives the Adonius an upbeat. If we have ever wondered what it is that makes his dramatic verse so musical, we find here a further secret than that of its everchanging tone-colour; its movement is continually diversified by these unmistakable lyric rhythms, which are yet so tempered with the plain sequences that the dignity of the verse is unimpaired. We have in the result that exquisitely varied music which our prosody has so long done its best to stifle.

In the following illustrations the measures which reproduce the Greek ones are referred to by the Greek letters by which they are distinguished above, and the arabic numerals denote plain measures according to the number of their feet. Thus

To be, or not to be : $\wedge \|$ that is the question. (3.a)

means that the line is composed of 3 unresolved feet of plain measure, $\checkmark \vdots-\sim|-\cup|-\wedge \|$, followed by the Greek measure designated above by the letter (a). The rhythm of the first six words, as distinct from their scansion, is iambic, but this disappears after the monosyllabic foot, and we have the rhythm $\bullet \cup \cup \mid \sim \cup \|$. We may note here the happy effect of the resolved foot; if we had had that's the question, the demonstrative would have received too much emphasis, and the latter part of the line would have been trivial and somewhat dead. We may now proceed with our illustrations. (The sign \| marks a change of measure, and is independent of the single lines that mark the scansion.)

As $\vdots \operatorname{mad}$ as the $\mid$ vex'd | sea, $\wedge \|$ singing a loud $\wedge \| . \quad(\beta, a)$

What a $\vdots$ haste | looks through his | eyes ! $\wedge \|$ So should he $\mid$ look. $\wedge \| \cdot \quad(\gamma \cdot a)$

That my : keen | knife $\wedge \|$ see not the | wound it | makes. (2. $\beta)$

In $\vdots$ this $\mid$ time of the $\mid$ night $! \wedge||$ Bring him a $\mid$ way $\mid . \cdot(\gamma \cdot a)$

Ring the a |larum-|bell. $\wedge \|$ Murder and treason! $(\boldsymbol{\beta} . a)$

What is a miss? $\Lambda \|$ You are, and | do not | know't $\wedge \|$. (a. $\beta)$

Ay, Greek, | that is my | name $\wedge \|$. $(\gamma)$

She is alone the Arabian bird, $\|$ and I. ( $\delta$ varied . 1)

I am : : ^ $\|$ what must we understand by this? (1.8)

All's $\vdots$ well, sir : || take my | power $i$ ' the $\mid$ court for | yours $\wedge \|_{\text {. }}$ (1.є)

Mark it: $\|$ the eldest $\mid$ of them at $\mid$ three years $\mid$ old $\wedge \|$. (1.t)

The combination $(\alpha, \beta)$ or $(\beta . \alpha)$ is especially common.

The point may be further illustrated by an examination of the structure of his verse periods. It was Shakespeare's constant ain, after his earliest years of production, so to manipulate his verse-by stops in the line, by linking the lines (enjambement), and by the introduction of short lines and Alexandrines - that it should not, as uttered, present a monotonous sequence of distinguishable 5 -foot lengths. The result is that in its most perfect form it falls upon the ear as a succession of 
measures of continually varied length, like those of an elaborate lyric. As one listens, it is only occasionally possible to tell where the written line begins and ends. Even the plain talk of a council-room is modulated in this manner:

Duke. There is no composition in these news

First Sen. Indeed they are disproportioned; $\|$

That gives them credit. $\|$

My létters say $\|$ a hundred and seven galleys.

Duke. And mine a hundred and forty. $\|$

Sec. Sen. And mine two hundred: $\|$

But though they jump not, on a just account,- $\|$

As in these | cases, || where the aim reports, ||

'Tis oft with difference- $\|$ yet do they all confirm

A Turkish fleet, $\|$ and bearing up to Cyprus. Oth. i. 3. 1.

In effect the measures of this period are : 7. $\beta .2 . \beta \cdot \gamma \cdot 2.5 . \alpha \cdot 3.2 .5 .3$. Examples meet one at every turn, but I have only space for two more, both short:

To cry to the sea that roard to us, $\|$ to sigh

To the winds \| whose pity, sighing back again, \|

Did us but loving wrong. Temp. 1. 2. 149.

Period: $\delta . \alpha .4 . \beta$.

Come, leave your tears: $\|$ a brief farewell : $\|$ the beast

With many | heads $\wedge \|$ butts me away. $\wedge \|$ Nay, mother,

Where is your ancient courage? Cor. 4. 1. 1.

In these two and a half lines we have five separate measures: 2.2.3. $\alpha . \delta$ varied, and may note especially the skilful use made of the resolved final foot. What an ear the man must have had! And yet there are those who will say that all this is to find in his verse a music that is not there. If the reader cares to look at Macbeth, 2. 2. 48-62 ('Why did you bring...green one red'), he will find that allowing for voice-pauses, the passage falls into the following measures: 5.2.2.4.2. $\beta . \alpha . \beta$.

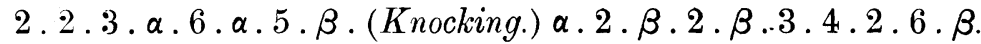

It remains to consider Dr Saintsbury's peremptory and contemptuous condemnation of the trochaic base, and what he has to say in support of his own view. Such is his infatuation for his iambo-trochaico-anapaestic scheme, that towards the end of his 3rd volume (p. 526) he becomes positively dithyrambic in praise of its charms, not scrupling to parody even the Authorised Version in order to elevate the style:

But still there abide these three-iamb, trochee, and anapaest-in the English aristocracy of poetry. The iamb is with us the staple of poetic life : it will do any work, take on any colour.... The trochee is the passion of life ; not easily adaptable by itself, except for special moments, comic or tragic, frivolous or plaintive, but seasoning and inspiring the iạmb constantly and yet strangely. And the anapaest is the glory of life, though its uses differ in glory....

M. L R. XIII. 
As the story of a mortal's passion for a phantom is always a little pathetic, so it is sad to see here so much enthusiasm spent in ecstasies over things that as metrical feet are no more than 'airy nothing.' To two of this ill-assorted trio Metre, as we have seen, refuses an abidingplace or even recognition, and Dr Saintsbury must be content to retain 'the passion of life.' Still he will find the trochee a more satisfactory general servant; it will do more work and put on less incongruous colours than the original staff. At p. 530, impatient with the dulness of those who cannot perceive his innamorata's perfections, he is betrayed into writing not quite politely, 'Some of these trochaisers seem to me to be prosodically rhythm-deaf as other persons are physically colourblind.'

So much for laudation of the defendant and abuse of the plaintiff's attorney; when we look for argument we find it, for all one can discover, on p. 525, where what is said, if I understand the diagrammatic printing aright, comes to this. If you take the line

$$
\text { And shake } \text { the yoke }^{\text {of inauspicious }}{ }^{\text {stars, }}
$$

and scan it $\checkmark-|\checkmark-|$ etc, it invites a 'rising intonation'- the voice seems to be going upstairs; if you scan it with trochaic feet,

And shake the

$$
\begin{aligned}
& \text { yoke of inauspicious } \\
& \text { stars, }
\end{aligned}
$$

it imposes a 'falling intonation'- the voice seems to be going downstairs, and the result is 'ludicrous, hideous, and false.'

$O$ this [logic], what a thing it is!

What careful handling it needs, if the camouflet is not to prove more damaging to oneself than to the enemy! The voice does indeed rise toward the end of that line, but it does so in sympathy with the sense. The voice does not rise in saying

Thy bones are marrowless, thy blood is cold,

although the so-called 'rising rhythm' of its five iambi is unvaried On the other hand, in saying the line,

$$
\text { Come, sir, we will better it in Pisa, }
$$

which is rhythmically as well as metrically trochaic, the voice rises con- 
siderably to the final word ${ }^{2}$. But with rare exceptions, in no heroic line but an inferior one do the words fall on the ear with an unbroken iambic or an unbroken trochaic rhythm all through, as they do in the following dreadful specimens:

And then she fell across the bed and swoon'd.

I. treated Belvidera like your daughter. (Otway.)

In a rhythmically good line the feet are broken up, either by a pause or pauses, or by the fact that the words fall into groups some of which have an iambic, others a trochaic rhythm. Thus in the very line quoted by Dr Saintsbury the rhythm, unfortunately for his argument, is not $\checkmark$ - all through ; it is this as far as yoke, but then the rhythm of the long and important word inauspicious, with its trochaic sequences, imposes itself, and these are moreover precisely the syllables which lift the line above the commonplace. The whole contention therefore falls to the ground. But that it should have been made at all, and obviously under the impression that it is sound, is remarkable; for it clearly rests on a confusion of metre with rhythm - a notion that the two are identical, and that when a line is recited, the syllables must be grouped according to the feet of the metrical scheme adopted! That the author actually means this, he has left us no room to doubt; for otherwise there is no point in his taunt of the 'trochaisers,' whom he calls 'rhythm-deaf,' showing by the terms chosen that he has not realised the distinction that exists between Metric and Rhythmic. Yet the distinction is continually forced upon us by two characteristics of verse which should hardly have escaped the notice of a prosodist. Firstly, that a pause of the voice, even if only the slight pause made after a word to give it emphasis, usually (though not always) gives to the part of the line immediately preceding the pause an iambic rhythm, if the break follows a stressed syllable, and always a trochaic rhythm if it follow's an unstressed one. Thus most of our lines end with an iambic rhythm; but if the last foot is completed, the final rhythm is trochaic; and so it is elsewhere in the line. Secondly, the argument takes no account of the fact that when a line is spoken, an attentive ear detects an iambic or trochaic rhythm, as the case may be, in certain individual words or combinations of words even when there is no pause at all, as in the case of inauspicious above. Even a disyllable is sufficient to change the rhythm and so redeem a line from monotony, as in the following and thousands of others :

'Twas pitiful, 'twas wondrous pitiful.

1 The terms ' rising' and ' falling rhythm' are in fact meaningless, and imply what is not true : for whether a word has the quantities - - or - -; the pitch of the voice for the second syllable may be either higher or lower than for the first, or it may remain unchanged. 
The matter is so important and apparently so little understood, that at the risk of labouring it needlessly, I will draw attention to a few lines from $M . N . D$. by way of further illustration. (The sign \| marks here a change of rhythm, and is independent of the single lines occasionally inserted to mark the scansion.)

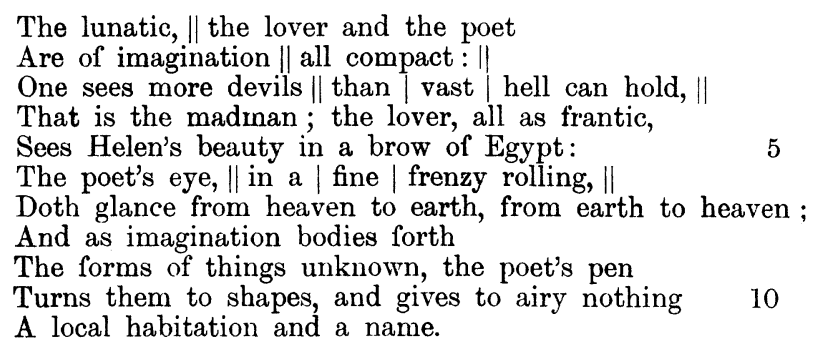

The rhythms here are:-The lunatic, iambic, but the rest of the line is trochaic; the 2nd line begins trochaic and ends with the rhythm of the 'cretic' - $\checkmark$ - in all compact. The $3 \mathrm{rd}$, by reason of the slight voicepause at devils, begins trochaic, but it ends iambic. The 4th is altogether trochaic, but is saved by the resolutions and the pauses. So the 5 th mainly; but there is a slight voice-pause at beauty, and since there is no stress on in, in a brow gives the rhythm $\checkmark \cup \leftarrow,-$ a delicate touch which, to my ear at least, makes the movement of the line as a whole peculiarly pleasing. In the 6 th we have an iambic rhythm in The poet's eye, and then a trochaic sequence (to which in a becomes a double upbeat), instinctively steadied by the monosyllabic foot fine. The 7 th is mainly iambic, but ends trochaic; for I take it that while neither heaven is monosyllabic, the $v$ and $n$ of the second are to be said with very great distinctness, heav- $n$. The 8th is dominated by the trochees of imagination, but melts into the 9 th, which is iambic, admirably relieved by the irrational un- in unknown. The 10th is a beautifully diversified line; metrically it begins with a triplet dactyl but, as recited, with a trochee followed by an iambus. The and, though scansionally belonging to the foot shapes and, attaches itself to gives as though it were the upbeat of a fresh line, so that we go on with an iambus and gives, but only to find that the rhythm has imperceptibly melted into a trochaic movement in the two final feet. The last line is markedly trochaic in local habitation, but ends with the iambus a name.

If, as I more than suspect, the iambic system originally grew out of a confusion of Metric with Rhythmic, being the result of a hasty deduction from the fact that most of our heroic lines begin and end with what is indeed rhythmically an iambus, this passage, like countless others, 
shows that such an appeal to rhythm is futile. Rhythm and Metre have elements in common, but as entities they are distinct. Rhythm in its widest sense denotes movement in regular succession, or a succession of regular movements; thus the pendulum of a clock and a dancer's feet move in rhythm. As applied to verse, the word usually denotes the movement, the mode of progression, of a line as a whole. This total of movement is made up of units of rhythm, which are of various kinds and lengths. Some are identical with the metrical feet of the measure employed; others are altogether independent of the foot-divisions as (in our triple measures) $\checkmark-, \cup-\cup,-v-, \cup v-$ (delight, delightful, discontent, with a cry) etc. Indeed it is no small part of the poet's art to see that his units of rhythm shall not correspond too frequently with the metrical feet. The units of rhythm must, however, be so adjusted to each other that they can be re-divided into the units of the metre, the 'feet,' each of which, unlike the units of rhythm, must have the same time-value; for otherwise metre (measure) vanishes, as it would from a foot-rule divided into uneven spaces. This re-division is the function of scansion, which takes no account whatever of the word-groupings on which sense and rhythm so largely depend. Further, the stresses of the metrical units, like those of the rhythm-units, must recur at regular intervals, or they will fail to admit and account for the rhythms of the verse. This is just what our traditional scheme fails to do ; it does not measure, because its stresses are irregular and its feet are not equivalents. To look at the matter from the opposite point of view, a poet may take a measure and write to it, introducing units of rhythm quite diverse from those of the measure, and different ones in different lines; but if, when his verse is scanned, his rhythms do not fit the measure perfectly, with the stresses falling as the measure demands, he has written what we call an unmetrical line.

Clearly, then, rhythm is one thing and metre another, and units of rhythm are not to be regarded as metrical 'feet' merely because they happen to occur in the verse. To interpret their presence thus is to miss the point under discussion. We are not now primarily concerned with rhythm. The question at issue is, what is the metre (capable of numerous varieties of rhythm, as all but short metres are) which underlies our heroic line? What is the skeleton which the poet disguises and transforms when he clothes it with his verse? One of the contentions of this paper-and all Dr Saintsbury's rhetoric leaves it untouched-is that the skeleton jumped together by the prosodists is a badly articulated rickety thing, incapable of the harmonious and rhythmical movements which 
characterise the living verse of the poets. Ask it to move with grace, or even ease, through any of the lines quoted above under $\$ 7$-say, Browning's line,

He will seem hardly more than a great boy,

and see the poor thing shuffle as it hesitates whether to put down its accenting foot on $\mathrm{He}$ or will-to be wrong whichever it selects, though it must choose one or the other ; mark how it misses the indispensable stress on seem, and as it hobbles on to the end, after shuffling once more in doubt between than $a$ and than $a$, how it bumps out for us either than $a \mid$ great bóy $\|$, or (deciding to 'reverse'!) | than a | great bóy $\|$, in either case failing to give great the stress it demands. Or if, moving in ' the glory of life,' it starts with an 'anapaest' and the correct stress on seem, note that it at once reverses for two turns, and having converted three-fifths of the line into a full dochmiac, ends with the beginning of another. For the paper-scansion

He will seém | hárdly | móre than $\mid$ a greát | bóy $\wedge$

produces in spoken effect

He will : seém hárdly | móre than || a $\vdots$ greát bóy -1 - 1.

Even and dignified progress is in fact impossible for this iambic-trochaicoanapaestic deformity by reason of its very structure, and there is more truth in Dr Saintsbury's words than perhaps he thought when he indiscreetly compared the 'interchanges' of the passionate trochee with his anapaests and iambs to the 'cross-hands and chassez-croisez and curtseys' of a country-dance - that merry romp of our younger days.

The metrical principles advocated in this paper are equally applicable to lyrics, but that most important branch of the inquiry must be reserved for separate treatment.

M. A. BAYFIELD.

HertingFordBuRy, HeRtFord.

1 This dochmitis is made to afflict Shakespeare passim: e.g. Hamlet, 3.2.386.

I will : spéak dággers | tó her, || but : úse nóne $-1-\smile \|$. 